\title{
Social Responsibility and Community Based Research in Higher Education Institutions
}

\author{
Budd Hall and Rajesh Tandon
}

\begin{abstract}
We are now at a key juncture in history. The neoliberals have had their turn at remaking the world and the resulting path of destruction is clear. They have created a world more unequal and anti-democratic than it has been since the Industrial Revolution. This faces public universities with a choice. Public universities can either become an integral element in the recreation of social democracy or can continue to operate as an instrument of elite domination of the planet.

GREENWOOD AND LEVIN (2016, p. 7)
\end{abstract}

Much recent debate about higher education has focussed upon rankings, quality, financing and student mobility. Larger questions about the social relevance of higher education have however taken on new urgency. The covid-19 pandemic, the climate crisis, the calls for decolonisation, the persistence of gender violence, the rise of authoritarian nationalism, have given rise to both a new era of uncertainty and perhaps to an opportunity for what some have called a great transition or a civilisational shift to a newly imagined world. We have reached a point where we have a limited capacity to understand the way forward but must have an unlimited capacity of caring for each other and the planet within which we are but one small part.

The social responsibility of higher education was chosen as the opening paragraph of the Conference Communique of the UnEsco World Conference of Higher Education (WCHE) in 2009. Specifically, the communique notes, "Higher Education as a public good is the responsibility of all stakeholders, especially governments" (p. 1). It goes on to note:

(C) BUDD HALL AND RAJESH TANDON, 2021 | DOI: 10.1163/9789004459076_001

This is an open access chapter distributed under the terms of the CC BY-NC 4.0 License. 
Faced with the complexity of current and future global challenges, higher education has the social responsibility to advance our understanding of multifaceted issues, which involve social, economic, scientific and cultural dimensions and our ability to respond to them. It should lead society in generating global knowledge to address global challenges, inter alia food security, climate change, water management, intercultural dialogue, renewable energy and public health. (p. 3)

The 2014 report by the Global University Network for Innovation (GUNi) states:

Social responsibility emerges as the need to reconsider the social relevance of universities in light of the encounter of the local with the global, regarding priorities, demands, impacts and knowledge needs in the context of globalization. The competitiveness of nations - as the only way to achieve progress - should be balanced with inclusive social development and sustainability of the entire global population. (p. 38)

This book is built upon a foundation of our thinking and practice over a period of 40 years. Our Unesco Chair, which sprung from the 2009 Unesco World Conference, provided us with an organisational framework for the theoretical and practical discourse that we have been engaged in since the 1970s (Hall et al., 2013, 2015, 2017a, 2017b; Tandon et al., 2002, 2016a, 2016b, 2017). As we have followed our mandate to build research capacity in the fields of community-based research and social responsibility in higher education in the global South and the excluded North, we have found ourselves in conversations, in conferences, in research projects and networks in all parts of the world where the question is being asked how should universities respond? What are the changing roles of the university today? Is the university contributing to our global crises or does it offer stories of hope? Our book is a contribution to the on-going debates and policy discussions which are critical for the future, a post-pandemic future, a future which moves the UN Sustainable Development Goals from lip service to action, a future where our climate crisis no longer remains the cry of the few, but the reason for action for the many. We have deliberately sought authors and viewpoints from parts of the world that have seldom been heard in the international literature on higher education and social responsibility. In contrast to books like these that most generally only feature writers from the global North, we have chosen to share the experiences of a broadly representative and globally dispersed set of writers. Importantly we have intentionally chosen to achieve a gender and diversity balance amongst our authors. This book features many younger and emerging scholars. 
We have done this to broaden perspectives on higher education where the overwhelming number of books are written by white European or North American males. While readers will find many familiar references, you will also find references to many new names from yesterday and today's Africa, Asia, Latin America and more.

In the years that have followed the 2009 World Conference on Higher Education, we have seen an extraordinary growth in policies, critiques, practices, theories and networks that have added significantly to a depth of understanding, identification of challenges and new architectures of knowledge in response to the calls for social responsibility. The creation of our UNESCO Chair in Community-Based Research and Social Responsibility in Higher Education as an example is one direct outcome of the WCHE. We have seen impressive work being done through national and global higher education networks and organisations such as the Association of Indian Universities, Association of Commonwealth Universities, Asia Pacific University Community Engagement Network, International Association of Universities, National Coordinating Council for Public Engagement in Higher Education, Global University Network for Innovation (GUNi), the Living Knowledge Network, PASCAL Global Observatory, and The Talloires Network.

The call to social responsibility has been elaborated in many parts of the world. Anamika Srivastava (2017) notes in the Raj Kumar study, The Future of Indian Universities, that "Social responsibility is universities' prime responsibility which should get manifested not only in their core activities buy also in their governance structure and institutional environment" (p. 329). A few years earlier in a submission to the Rae Commission, Ontario's Postsecondary review, it was noted, "The social contract with universities is formulated over time and shaped by history. [...] The social contract requires continuous reflection and dialogue among the university and society as each era renews the social contract according to its needs" (2005, p. 37). It reminds us of the 1972 report on Creating the African University which noted that, "the truly African University must be one that draws its inspiration from its environment: not a transplanted tree, but one growing from a seed that is planted and nurtured in the African soil" (Yesufu, 1973, p. 33). Ron Barnett (2018) in his book on the 'ecological university' notes that the university is now back 'in' society and that if once, the phrase, 'the ivory tower' had any legitimacy, now the phrase has no prospect of its being a serious depiction of the academy's situation. And in his recent book on Higher Education in a Globalising World, Peter Mayo (2019) comments, "There has been a general groundswell of reactions against the neoliberalisation of universities in many parts of the world, a reaction where people cling to the idea of knowledge and learning as a public and not 
a commodified good" (p. 11). For purposes of structuring this book we have chosen to speak about social responsibility within a knowledge democracy framework as being composed of several higher education directions: as a civic space for learning, as decolonised and local curriculum development, as engaged teaching and action, and as research which negotiates knowledge and society.

The concepts of engagement, public engagement, community-university engagement, engaged teaching, community engaged learning, covers another wide range of responses to the call for social responsibility in higher education. Universities will need to implant engagement into their culture, mores, policy-making and daily life. What historically has been called the 'Third mission' of the university after teaching and research as the first and second missions is being replaced by an understanding of engagement which is called upon to be all-informing. Ahmed C. Bawa, Chief Executive of Universities South Africa elaborates:

\begin{abstract}
University mandates throughout the world have statements that relate to community-based engagement in some form or other. It is important to understand why it is that this has happened, what forms these take, what effects they have on universities, what effects they have on communities with which they are involved, what effects these have on the students who are involved, how they relate to teaching, learning and research and how they are organised internally in terms of the structures and governance of universities. (2007, p. 55)
\end{abstract}

The 2014 GUNi report, Knowledge, Engagement and Higher Education: Contributing to Social Change has provided the most extensive global compendium on the discourses of engagement. With reports from 70 countries and over 100 contributors, World Report 5 is the benchmark by which the engagement 'movement' can be judged at a global level.

The report offers us elements of a vision for a renewed and socially responsible relationship between higher education, knowledge and society. [...] The report calls upon policy-makers and leaders of HEIs around the world to rethink the social responsibilities of higher education in being a part of society's exploration of moving towards a more just, equitable and sustainable planet. (GUNi, 2014, p. xxxi) 
Sophie Duncan and Paul Manners have led the UK National Coordinating Centre for Public Engagement in Higher Education (NCCPE) since its inception in 2008. They note, "Principles of engagement capture the imagination and commitment of many of those working in HE. [...] But this only takes us so far. Shifts in funding priorities ... provide an equally important driver in the system" (2012, p. 222).

The UNESCO Chair in CBR and SR in HE has led research and writing of two global studies in community-engaged and community led research, Strengthening Community University Research Partnerships: Global Perspectives and Knowledge (2015) and Engagement: Building Capacity for the Next Generation of Community Based Researchers (2016). These global studies involved global surveys and both national and institutional case studies to illustrate how community-based research was being institutionalised around the world and how and where people were learning how to do community-based research. The findings from these two studies have provided the theoretical and practice underpinnings of the Knowledge for Change $\left(\mathrm{K}_{4} \mathrm{C}\right)$ Consortium, a network of local community-based participatory research training centres that have emerged in the global South and the 'excluded' North. ${ }^{1}$

\section{3}

\section{United Nations Sustainable Development Goals}

The United Nations (UN) universally adopted the Sustainable Development Goals (SDGs) in 2015 as a beacon for socially, economically and ecologically sustainable development. Agenda 2030 establishes 17 Goals which are universally applicable for all countries of the world (United Nations, 2017). Within these globally agreed upon and universally applicable SDGs, many countries, including regions such as provinces and territories, have developed specific national and locally relevant benchmarks and indicators for achieving these commitments. Sustainable development in practice includes many efforts at defining the concept, establishing goals, creating indicators, and asserting values. Additionally, it also includes developing social movements, organising institutions, crafting sustainable science and technology, and negotiating the grand compromise among those who are principally concerned with nature and environment, those who value economic development, and those who are dedicated to improving the human condition.

While these SDGs are broadly acceptable to all countries and peoples, and have been developed through an extensive consultative process to enable wider ownership; achievement of this ambitious agenda by 2030 faces several capacity deficits (Tandon, 2017). 
- Ensuring sustained political support from leadership of governments at the national and sub-national levels. Political leadership in most democratically governed jurisdictions tends to take decisions in the short-term (3-4 years at most), with a view to win the next elections. This severely limits continuity of policies and programmes over the SDG timeframe.

- The investment of adequate resources in each country and region. In contemporary economic environment, it is uncertain if all countries, and the global community, would have adequate financing deployed towards all the SDGs.

- Institutional and human capacities affect the implementation of practical strategies for achievement of the SDGs in many countries. Most public institutions are designed to function in silos, pursuing narrow objectives. In contrast, most SDGs can only be achieved through simultaneous actions on several issues. For example, achievement of SDG 5 - on gender equality - will not be possible without achievement of SDG 3 \& 4 . SDG 3 focuses on health, including women's health, while SDG4 focuses on education, especially targeting girl's education. Both these goals can only be achieved in many societies when patriarchal attitudes change to prevent violence against girls/women and to enable mobility.

- Knowledge deficit could be argued as the most critical deficit confronting the achievement of the SDGs. Existing knowledge systems are founded on the principle of instrumental rationality. Modern science practiced over the past three centuries is posited on the premise that scientific knowledge can be used to control and mine nature and its huge resources (Tandon, 2002). Alternative perspectives of knowledge are required to fill this knowledge deficit in ways that learning and collaboration are organically linked to generating locally relevant solutions for the SDGs (Tandon et al., 2017).

Higher education and its myriad of institutions, with an enormous number of resources at their disposal (human, physical, digital) can also address the learning and collaboration deficit in the achievement of the SDGs. Sustainable development cannot be achieved anywhere in the world "without the capacity-building contribution of an innovative higher education system" (University World News, 2017). This is the key message that came through the international consultation convened by Association of Commonwealth Universities (ACU) in 2013.

The higher education sector's efforts to prepare to respond to the post2015 agenda require new thinking in terms of scale and modality. As national institutions addressing global challenges, universities need to be able to 
incorporate diverse demands and diverse stakeholders into their own agendas. Contributors also highlighted the need for change and adaptation within the sector (ACU, 2015).

Education is one of the key aspects of the SDGs, with SDG4 calling for the world to 'ensure inclusive and equitable quality education and promote lifelong learning opportunities for all' by 2030, while target 4.7 specifically calls for the 'development of skills and knowledge for sustainable development and sustainable lifestyles'. Further, higher education forms an important part of other goals related to poverty (SDG1); health and well-being (SDG3); gender equality (SDG5) governance (SDG16); decent work and economic growth (SDG8); responsible consumption and production (SDG12); climate change (SDG13); and peace, justice and strong institutions (SDG16). Engaging with the SDGS can also benefit universities by helping them to demonstrate impact, increase demand for SDG-related education, build new partnerships, access new funding streams, and define a university that is socially responsible, locally rooted and globally engaged. Such a contribution from higher education institutions is possible if higher education is viewed within the larger societal context, and not merely as educating for jobs and livelihoods.

Therefore, higher education will play a prominent role across most SDG priorities, which include an end to poverty and inequality, and scientific progress in areas such as climate change and economic growth, a major priority of developing countries. Peter J. Wells, Chief of the Higher Education Division at UNESCO noted at the annual meeting of the Council for Higher Education Accreditation's International Quality Group or CIQG in Washington in early 2017 that "UNESCO already has begun to tap university expertise and cooperation as 'incubators of solutions' through its University Twinning and Networking initiative" (Marklein, 2017).

\section{Knowledge Democracy}

Knowledge democracy refers to an interrelationship of phenomena. First, it acknowledges the importance of the existence of multiple epistemologies or ways of knowing such as organic, spiritual and land-based systems, frameworks arising from our social movements, and the knowledge of the marginalised or excluded everywhere, or what is sometimes referred to as subaltern knowledge. Secondly it affirms that knowledge is both created and represented in multiple forms including text, image, numbers, story, music, drama, poetry, ceremony, meditation and more. Third, and fundamental to our thinking about 
knowledge democracy is understanding that knowledge is a powerful tool for taking action to deepen democracy and to struggle for a fairer and healthier world. Knowledge democracy is about intentionally linking values of democracy and action to the process of using knowledge.

Knowledge democracy is emerging as an umbrella concept which allows for the integration of many approaches to knowledge and society. The European Commission support of Science With and for Society (swAFs) and Responsible Research and Innovation (RRI) has been an important if regionally contained approach to knowledge democracy. Conceptual work linking knowledge, equity, democracy and engagement can be found in the thinking of de Sousa Santos (2007), Gaventa and Bivens (2011), Sörlin and Vessuri (2007), and Tandon (2014). Gaventa and Bivens note that, "without cognitive justice, which focuses on whose knowledge counts, the larger struggles for social justice will not be realized" (p. 1). A term that is increasing used to describe an active, engaged and values-based understanding of knowledge is 'knowledge democracy'. Knowledge democracy or epistemic justice is linked to the deeper transformations that our times are calling for. De Souza Santos provides arguably the richest conceptual approach to an inclusive understanding of knowledge. The global lines that he is referring to are those that separate the visible constituents of knowledge and power from those who are invisible. For de Souza Santos, the way forward lies in the concept of 'ecologies of knowledge'. An ecology of knowledge framework is centred on knowledge from the 'other side of the line', what others speak of as excluded knowledge.

Knowledge democracy is in part the idea that knowledge is to be measured through its capacity to intervene in reality and not just to represent it. An intelligent society must be ready to generate knowledge (ideas, instruments and procedures) corresponding with transnational knowledge societies and networks. The idea of an intelligent society recognises that all human beings have the capacity to create knowledge in the context of creating a new way of living or a new society. Now is the moment to widen the scope of knowledge in society and to move beyond creating socioeconomic well-being towards a true knowledge-based society, through engagement with citizenry as a whole, at all scales of activity, to dealing with the problematic issues of the day and the global issues. Knowledge must contribute to society's incorporation of sustainability shift paradigms. We need to connect different kinds and sources of knowledge and facilitate understanding between different cultures, forging links between knowledge and citizenship. This is necessary to break conformity of thought by proactively criticising the world of ideas. The creation and dissemination of knowledge could contribute to transforming the paradigms and beliefs established in social, economic and political systems, and 
to moving forward to creative and innovative ways of thinking and imagining new realities.

Knowledge could also help in ethical awareness and facilitate the civic commitment of citizens and professionals. It is an important moment for looking more deeply at the ethical, social and environmental implications of the advance of knowledge, and to increase the resources invested in analysing the impact of science and technology in society. Knowledge is also linked with democracy, citizenship, inter-cultural relations, recognition of interdependence, new approaches to health and well-being, rights, mutual comprehension, peace-building and a deep understanding of life's dynamics. Society needs to incorporate complexity and uncertainty in the way problems are analysed and assumed. We know there is a need to link multiple areas of knowledge that are complementary in the capacity to deal with complex problems and find solutions in the local and global context. Local needs require local proposals in global frameworks, and global challenges require global solutions that are locally acceptable. However, global solutions can come from local experience and vice versa. How we facilitate networking among a range of different social actors and levels of activity is also important. Coupling research, decision making and development to inform political decisions that affect large segments of population is a key issue to tackle for the collective well-being. We understand knowledge democracy through seven principles: decolonisation and the recognition of multiple epistemologies, respect for the co-construction of knowledge, broadening our research methods tool kits, sharing research findings beyond the academy, recognising knowledge at the heart of transformative action, recognising the rights of Indigenous communities and others to own, control, access and possess their own knowledge (OCAP) and free and open access to most research findings.

\section{Organisation of the Book}

The structure of our book takes into account the need to explore how the various issues we have foreshadowed in our introduction are taken up in case studies and stories from the diverse parts of the world that have been included. A socially responsible higher education institution is one which address four fundamental principles: universities as civic spaces for the development of new democratic practices, curricula that are decolonised, pluriversal, locally contextualised and land-based, teaching and learning that is community engaged and action oriented, and where new understandings of knowledge relationships with society and our planet are being negotiated. 


\section{1}

\section{Universities as a Civic Space}

We begin with the idea of higher education being a civic space for learning. We are reminded of Rabindranath Tagore's vision of education as noted by Abhik (2017) that,

The ultimate goal was to improve the conditions of people who are marginalized. Tagore was of the opinion that the primary role of education was transformative: changing the hearts and minds of students in order for them to relentlessly strive to create world communities that are founded on peace, universal brotherhood and sisterhood. (p. 1)

The simplicity of his idea was that university students and their instructors would know people in the community and that by knowing each other would experience a flow of knowledge back and forth between people with different roles in life but with common hopes.

Ana Maria Tejera, Anna Maria de Albuquerque Moreira, Marcia Lopes Reis and Sebastian Schurman open this section with an examination of the efforts being made by higher education institutions in Argentina, Brazil and Uruguay to reduce inequalities by incorporating previously excluded minorities from access. They note that their universities are experiencing a tension of responding to huge demands for new places in universities while at the same time trying to become more engaged in the very communities where they are located.

Kanya Padayachee, Darren Lortan and Savathrie Maistry write from South Africa about the tug of war between those calling for the university to prepare students for the corporate global market and those calling for preparation to play a role creating a more democratic public good. Drawing on both Gandhian philosophy and the philosophy of Ubuntu, they put forward the case for life-centred engagement, collective knowing and Indigenous ways of knowing as foundations for a South African practice of social responsibility and what they call the intercultural university.

Kapil Dev Regmi, a Nepali scholar, describes developments in higher education in Nepal over the past years as dominated by external funders including the World Bank. The purposes of higher education according to the dominant discourse have been to help Nepali students and Nepal itself become more firmly entrenched into a corporate knowledge economy. Nepal as a land of ancient Indigenous ways of knowledge has been lost under a call for 'modernisation' which means jobs for markets. Using a Habermasian lifeworld framework, he demonstrates how higher education is disconnected from community. Rural people are not knowers. Social responsibility will happen with a reconnection to the lifeworld and cultural spheres. 
Benita Moolman and Janice McMillan share their experiences in creating a course at the University of Cape Town in South Africa in Engineering and the Built Environment. It is a course which is framed in a pluriversal framework of multiple knowledges with a focus on the co-creation of knowledge, engaged learning and social justice. Social responsibility from their perspective has to include understanding our locations of privilege; who we are and who we are not.

University Wankings (UW) is the Twitter handle for an anonymous scholar who challenges the rise of higher education rankings. Uw builds on a discourse of privilege, entitlement and power differences raised by Moolman and McMillan putting forth a critique of rankings as reinforcing the domination of white Eurocentric knowledge as the global standard of excellence. UW points out that $90 \%$ of the top universities in the world according to the Times Higher Education rankings are in the global North. There are 25 in Asia, three in South Africa, one in Latin America and one in the Middle East. They suggest that White universities will resist any changes that would threaten their position at the apex of the higher education food chain.

Florence Piron, Tom Olyhoek, Ivonne Lujano Vilchis, Ina Smith and Zakari Lire build on the chapter from University Wankings going deeper into the ways in which metrics are used in the scholarly world to privilege English-language, global North and market-owned journals over those published in majority world languages, in non-profit and other open access publishing houses. They suggest that knowledge democracy principles are needed to build more equitable platforms for knowledge sharing.

\subsection{Curricula:Decolonised, Local and Place-Based}

The second space within the world of higher education where social responsibility interacts with the structures of learning is in the realm of the curricula. What courses are offered? What teaching designs are used? What forms of engagement beyond the classrooms are offered? What role do knowledgeable people in the community have in teaching or curriculum design?

James Cuenca Morales and Claudia Lucia Mora Motta share experiences with the creation of the Javariana Training Programme for Social Change and Peace. They speak of the power of the 'hidden curriculum' of campus life. Their training programme co-constructs curriculum with people living in the community. The community engagement in the Social Change and Peace course continues over time working with different cohorts of students.

Anđela Jakšić-Stojanović brings an experience from Montenegro which incorporates 'community learning' into her classes in art education. Her students were given the challenge of designing and executing a new interior painting project 
within a children's hospital. She notes that the discourse of social responsibility is spoken about in Montenegro higher education, but not put into practice. Her course is innovative within their system with students co-designing the course, including offering art education workshops for children in the hospital.

Anna Nahirna and Olha Mykhailyshyn help us to understand another dimension of knowledge democracy. Their work with the Ukranian Catholic University's Emmaus Centre is influenced by the work of the Canadian Jean Vanier. They speak of gifts of knowledge that persons who are labelled as developmentally disabled offer to any of us. The differently labelled bring the knowledge of relationships and help others to understand their need for the weak.

Emna Belkhiria, Mazhar al-Zo'by and Arslan Ayari from the University of Qatar challenge the impact of globalisation on higher education noting that globalisation has, "ushered in a new era of cultural and linguistic imperialism". In 2012 the Qatari higher education authorities called for shifting the language of instruction from English to Arabic. They have done this to strengthen the place of Arabic as a language of the highest level of sophistication and to underscore elements of culture and identity.

Bohdan Krawchenko, Zalina Enikeeva, and Tamara Krawchenko working from the fairly new University of Central Asia in Kyrgyzstan write about the slow transition being made by higher education in Kyrgyzstan. Kyrgyzstan is a land-locked country located in the peripheries of the former Soviet Union. The Kyrgyz are the original Indigenous people of the territory. Their chapter serves in some ways as a clarion call to higher education in a country that is open to change and wanting to serve their people.

\subsection{Engaged Teaching and Action}

We begin with the university as a civic space, we open up the conversation about what is taught and how is that structured with the community in mind. Our third section brings us stories of engaged teaching and action. It is important to note that when these approaches to social responsibility keeping knowledge democracy in mind, are working in practice the walls between community, the classroom and teaching fade away. Engagement is the leavening agent allowing the bread of social responsibility to rise in all parts of our higher education institutions.

Anita Kumari and Pratikalpa Sharma from the Gujarat National Law University provide readers with an example of how the Centres for Excellence in Research associated with the 19 National Law Universities (NLUS) are contributing to the challenges of social responsibility. Taken together, the NLUs' research centres support a variety of the UN Sustainable Development Goals 
through their focus on social exclusion, human welfare, legal aid for the poor, women and children's welfare and sustainability.

Estelle Baurès and Alessia Lo Porto-Lefébure share their experiences with the teaching of public health in France with reference to the UN SDGs. They are associated with the Ecole des hautes études en santé publique (EHESP), the leading public health higher education institution in France. France has gone further than many other jurisdictions in efforts to institutionalise social responsibility. Higher education institutions are able to acquire special recognition for putting into practice a set of curricular, engagement, research and teaching practices in support of principles of sustainable development and social responsibility. Teaching at the EHESP builds on engagement and diversity.

José Sepúlveda Maulén from Chile brings the well-established Latin American theory and practice in service-learning as expressed by the Centro Latinoamericano de Aprendizaje y servicio solidario (CLAYss), that learning serves a much bigger purpose than just passing an exam, and that being socially engaged teaches what only the best schools can teach: how to build a better world with and for everyone. He notes that there are tensions in the way that university social responsibility (USR) has been recently taken up. In many places USR has followed corporate social responsibility paths towards a charity-based idea of 'helping' the needy. This chapter calls for teaching that positively impacts society and the environment in ethical and transparent ways.

Renata Bregaglio, Renato Constantino and Paula Camino add to our reflections on the teaching of law in Peru. They inform us that in 2014 legislation was put into place mandating that social responsibility was to be put in place in every university in Peru. This legal requirement understands social responsibility as, "A series of actions and values, stemming from civic commitment and engagement that requires administrations, students and faculty to engage with the communities around them in a sustainable manner". Law schools have interpreted this mandate by drawing attention to their community law clinics, clinics which provide opportunities to work on behalf of community clients while they are studying. In spite of the legislation, the authors indicate that challenges of a lack of institutional support and lack of adequate staffing remain.

\subsection{New Understandings of Knowledge, Humanity and the Earth}

The last section of our book draws attention to the need for and the visible actions that can be seen as society is engaged in a renegotiation with higher education institutions around the representation, use of and roles of knowledge in today's world. The monopoly once held by universities as the managers 
of knowledge for society has been broken. The experiential knowledge of the poor, of health patients, of students, of women in domestic violence, of industrial workers, of consumers is transforming our professions, is organically harvested by digital technologies and is opening the doors of our higher education institutions. Indigenous peoples in every part of the world are reclaiming their teachings and wisdom. Ecologies of knowledge, pluriversal understandings of knowledge, holistic learning and knowledge democracy are places where just some of the discourses can be found.

Sarita Anand is a Professor in Visva-Bharati, Santiniketan in West Bengal India, a higher education institution created over 100 years ago by the late Nobel Prize winning poet, philosopher and visionary, Rabindranath Tagore. The Tagore vision needs to be understood along with other radical transformative education figures such as Paulo Freire or Gandhi. His idea that teachers, students and the people of the communities would know each other and work together for the betterment of all living in those communities was an expression of social responsibility as a natural and organic set of relationships. Tagore created a remarkable number of social, cultural and spiritual spaces where all people could share knowledge. The various festivals created in the early zoth century are still celebrated today. Academics might refer to these as space of knowledge mobilisation. One of the objectives then as today is the linking of community and university intellectuals.

Catherine Déri draws out attention to the contradictory and dangerous ways that internet-based knowledge circulates as a source of recruitment and inspiration for extremist movements that use violence as a method. She calls on higher education institutions when thinking about the dimensions of social responsibility to take into consideration measures that counter violent extremism. She references Raymond Williams who said, "To be truly radical is to make hope possible rather than despair convincing".

Jana Berg writes on the inclusion of refugees in higher education as an important indicator of social responsibility. Writing from Germany, she says that only $3 \%$ of refugees there have access to higher education. In a world with over 6o million refugees how can universities address the aspirations of these people forced from their homelands? She also notes that the term social responsibility is ambiguous and often interpreted in status quo ways.

Muzaimi Mustapha, Aileen Tan Shau Hwai, Asyirah Abdul Rahim and Darshan Singh are with the Knowledge for Change community-based training hub at Universiti Sians Malaysia. They describe the transformation over the past 20 years of one of Asia's most respected universities towards community, towards the environment and towards a vision of supporting the 'bottom billion' poorest persons in the world. The Malaysian philosophy of Sejahtera is a holistic 
concept drawing together the pursuit of peace, tranquility, harmony, wellness and health. Sejahtera needs to be added to other concepts in our book such as Ubuntu when thinking of non-western approaches to social responsibility.

A European framework for community engagement (TEFCE) is the focus for Thomas Farnell and Bojana Ćulum Ilić from Czechoslovakia. The TEFCE project has resulted in what they call a toolbox for supporting the many dimensions of community engagement, tools that could as easily be seen as developmental tools for assessing and building social responsibility. TEFCE project goes beyond much of the social responsibility and community engagement literature in noting that the key question is, "How mutually beneficial are the partnerships with the communities". The toolbox, unlike rankings which have proven to be toxic, is not an instrument for comparisons, but is developmental.

Sebastián Fuentes from Argentina provides us with background on the evolution of the university extension model of social responsibility which has been adopted in most of Latin America. Noting a variety of central government policies in support of a renegotiated community-university space, he also draws attention to the creation of a course in psycomotricity, a discipline that links mental and physical activity. This course is innovative and in his ideas is an example that changing society means changing universities as well and viewing communities as teachers.

Florence Piron, Tom Olyhoek, Ivonne Lujano Vilchis, Ina Smith, and Zakari Lire in their second chapter in this book share case studies from Europe, Francophone West Africa, South Africa and Latin America on the evolution of free open access publishing as a way of countering the predatory and exclusionary practices of the market-based publishing academic industry. The promotion of these new spaces for new scholars, non-English speaking scholars, global South scholars publishing are a cornerstone of knowledge democracy.

\section{An Offer of Hope}

Perhaps the cruelest outcome of the past 50 years of unbridled and feral capitalism has been the sense that there is no better way to organise the world. While the widening gaps between the rich and the poor are disheartening, the abandonment of the imagination about how we might live together with each other and our living planet to the market intellectuals is the most tragic of all. We are called to take back the right to imagine, the right to a new utopia. The stories in this book show us that the future is with us now in smaller and larger ways. Universities have changed before in earlier times. They can and in fact are changing again. We enter into these moments of radical uncertainty with hope. 


\section{Note}

See www.unescochair-cbrsr.org

\section{References}

Abhik, R. (2017, July 29). Tagore on education. The Statesman.

https://www.thestatesman.com/opinion/tagore-on-education-1501361209.html

Alveres, C., \& Saleem Faruqi, S. (Eds.). (2012). Decolonising the university: The emerging quest for non-eurocentric paradigms. USM Press.

Barnett, R. (2018). The ecological university: A feasible Utopia. Routledge.

Bawa, A. (2007). Rethinking the place of community-based engagement at universities. In L. McIlrath \& I. Mac Labhrainn (Eds.), Higher education and civic engagement: International perspectives. Ashgate.

Chang, D. W., Morshidi, S., \& Dzulkifli, A. R. (Eds.). (2019). Higher education in Malaysia: A critical review of the past and present for the future. USM Press.

Duncan, S., \& Manners, P. (2012). Embedding public engagement within higher education: Lessons from the beacons for public engagement in the United Kingdom. In L. MacIlrath, A. Lyons, \& R. Munck (Eds.), Higher education and civic engagement: International perspectives (pp. 221-240). Ashgate.

Gaventa, J., \& Bivens, F. (2014). Knowledge democracy, cognitive justice and the role of universities. In World report on higher education. GUNi and Palgrave.

Greenwood, D., \& Levin, M. (2016). Creating a new public university and reviving democracy. Berghahn.

GUNi. (2014). Knowledge, engagement \& higher education: Contributing to social change (Higher education in the world 5). Palgrave.

Grau, X., Tandon, R., Hall, B., \& Hazelkorn, E. (Eds.). (2016). Towards a socially responsible university: Balancing the global with the local: The VI world report on higher education. GUNi.

Hall, B. (with Tandon, R., \& Tremblay, C.). (2015). Strengthening community university research partnerships: Global perspectives. University of Victoria Press and PRIA Press.

Hall, B. (with Jackson, E., Tandon, R., Lall, N., \& Fontan, J.-M.). (2013). Knowledge, democracy and action: Community-university research partnerships in global perspectives. MUP.

Hall, B., \& Tandon, R. (2017a). Participatory research: Where have we been, where are we going? A dialogue. Research for All, 1(20), 365-374.

Hall, B., \& Tandon, R. (2017b). Decolonization of knowledge, epistemicide, participatory research and higher education. Research for All, 1(1), 6-19. 
Inman, P., \& Schuetze, H. (Eds.). (2010). The community engagement and service mission of universities. NIACE.

Inuit Tapiriit Kanatami. (2018). National inuit strategy on research. Nunavut Government.

Kumar, R. (Ed.). (2018). The future of Indian universities: Comparative and international perspectives. Oxford University Press.

Levin, M., \& Greenwood, D. (2017). Creating a new public university and reviving democracy: Action research in higher education. Berghahn.

Marklein, M. B. (2017, February 5). Quality assurance, higher education and the SDGs. University World News.

Mayo, P. (2019). Higher education in a globalising world: Community engagement and lifelong learning. MUP.

McIlrath, L., \& Mac Labhrainn, I. (2007). Higher education and civic engagement: International perspectives. Ashgate.

O'Malley, B. (2019, July 21). UN SDGs cannot be attained without higher education UN told. University World News, 567 .

Preece, J., Ntseane, P. G., Modise, O. M., \& Osborne, M. (Eds). (2012) Community engagement in African universities: Perspectives, prospects and challenges. NIACE.

Rae, B. (2005). Ontario: A leader in learning: Report and recommendations. Ministry of Training, Colleges and Universities.

Sorlin, S., \& Vessuri, H. (2007). Knowledge society vs knowledge economy: Power and politics. PalgraveMacMillan.

Sousa Santos, B. de. (2007). Beyond Abyssal thinking: From global lines to ecologies of knowledge. Eurozine, 33, 45-89.

Spooner, M., \& McNinch, J. (Eds.). (2017). Dissident knowledge in higher education. URegina Press.

Srivastava, A. (2017). Deconstructing the discourse on university social responsibility. In C. R. Kumar (Ed.), The future of Indian universities. Oxford University Press.

Tandon, R. (2002). Science, rationality and environmental ethics. http://192.9.200.201/ cgi-bin/library?a=q\&r=1\&hs=1\&e=q-ooo-oo---orajesht1--oo-o-o--oprompt-10--4----ddc--o-1l--1-en-5020-about-instrumental--ooo31-oo1-1-outfZz-8-oo\&h=ddc\&t= $1 \& q=$ rationality

Tandon, R. (2014). Community and civil society as sources of knowledge. World report on higher education. Palgrave.

Tandon, R. (2017). Making the commitment: Contribution of higher education to SDGs. http://unescochair-cbrsr.org/pdf/resource/Making\%2othe\%2oCommitment_ SDGs-Sep_2017_final.pdf

Tandon, R. (with Hall, B., \& Lepore, W.) (Eds.). (2016). Knowledge and engagement: Building capacity for the next generation of community based researchers. University of Victoria and PRIA. 
Tandon, R., Singh, W., Clover, D., \& Hall, B. (2016). Knowledge democracy and excellence in engagement. IDS Bulletin: Engaged Excellence, 47(6), 19-35. https:/opendocs.ids.ac.uk/opendocs/bitstream/handle/123456789/12748/ IDSB47.6_10.19o881968-2016.197.pdf?sequence=1\&isAllowed=y

The Association of Commonwealth Universities (ACU). (2015). Progress and potential: Higher education playing its part in the Sustainable development goals. https://www.acu.ac.uk/publication/download?publication=540

UNESCO. (2009). 2009 world conference on higher education: The new dynamics of higher education and research for societal change and development. Final Communique. Author.

United Nations. (2017). Website. https://sdgs.un.org/goals

University World News. (2017, February 5). Quality assurance, higher education \& the SDGs.http://www.universityworldnews.com/article.php?story=20170205044427645 Yesufu, T. M. (1973). Creating the African university: Emerging issues in the 1970s. Report of the Proceedings of the 1972 Accrah Ghana conference of the African Association of Universities, Oxford University Press. 